\title{
IFRS 9 AND IMPLICATIONS OF "BUSINESS MODEL VS. MANAGEMENT INTENT" CRITERIA ON THE QUALITY OF ACCOUNTING INFORMATION
}

\author{
Goranka Knežević ${ }^{1 \star}$, Vladan Pavlović , Predrag Vukadinović ${ }^{1}$ \\ ${ }^{1}$ Singidunum University, Faculty of Business in Belgrade, 32 Danijelova Street, Belgrade, Serbia \\ ${ }^{2}$ University of Pristina, Faculty of Economics, 156 Kolasinska Street, Kosovska Mitrovica, Serbia
}

\section{Abstract:}

The purpose of this paper is to determine the changes proposed by the IFRS 9 - Financial instruments, regarding the classification of financial assets and its effects on the financial position of a business entity and the results of operations in comparison to the former criteria established by the IAS 39 Financial instruments: recognition and measurement.

The issuance of the IFRS 9 in July 2014 was seen as the final stage in the project that IASB established regarding the financial instruments. The business model criteria used by the IFRS 9 are based on the financial, contractual cash flow incurred by the financial instrument or the cash flow caused by selling the instruments. Their proponents believe that these criteria are well-structured, objective and can be easily implemented by the users of financial statements.

The former criteria in IAS 39 are based on the management intent regarding the instruments and some proponents of the new standard believe that they cause more judgment and earnings volatility than the newly established criteria. The purpose of this paper is to indicate that the change of classification criteria did not meet the specified goals regarding the comparability of financial statements and possible earnings volatility. The only goals met are related to information relevance and confidentiality.
\end{abstract}

Key words:

IFRS 9,

financial instruments, classification criteria, fair value, management intent, business model.

\section{INTRODUCTION}

The very first standard regarding financial instruments measurement and classification issues was IAS 39 Financial instruments: recognition and measurement. It was issued in the times after the savings and loan crisis in the United States (1990-ies) and it puts an emphasis on measurement criteria for the financial instruments. The crisis revealed that the savings and loan institutions had assets measured by the historical cost and that the real market value of these assets evaporated during the crisis. The total assets were overvalued and that is why the standard setters needed to change the measurement rules for the financial instruments by introducing a fair value as a better and more objective measurement of the assets used by the financial institutions. A new standard named IAS 39 Financial instruments: recognition and measurement introduces the four categories in which financial assets can be classified. Each of the categories has different measurement rules. IAS 39 establishes fair value measurement to be used for sale and trading category, while the loans and receivables held to maturity are still recognized by using the amortized cost/historical cost method. It seems that the IAS 39 forbids the usage of historical costs in most of the cases regarding financial instruments and it limits it to the two main categories where almost all financial assets are recognized in non-banking portfolios and about $33 \%$ of large bank portfolios. Classification of financial instruments in this standard was based on management intent and the real, detailed criteria of the intent were not developed by the standard setters and that leaves the room to exercise professional judgment which affects earnings. Intent captured management plans to operate the business and the outcomes of the plans. It means that a financial instrument is placed in some of the above mentioned categories based on management plans with that instrument. The main question is what happens with the instrument when the intent of managers change from time to time driven by economic factors. Changes in intent affect measurement and the treatment of gains and losses regarding the financial assets of the specific entity making financial statement figures more volatile. Academic debates whether the fair value or historical cost is proven to be better measurement principle (Laux \& Leuz, 2009) and the debate about classification criteria (Leisenring et al., 2011) still exists. IAS 39 was considered to be one of the most sophisticated accounting standards issued by the IASB, especially in the area of classification with four mutually exclusive categories of instruments and different accounting treatment for each instrument. After the financial crisis in 2008 the classification criteria drew the attention of standard setters once again and they were changed with the introduction of IFRS 9. IFRS 9 leaves the intent model and establishes the business model criteria to classify the financial assets into three categories: financial assets at fair value through profit and loss, financial assets at fair value through other com- 
prehensive income and financial assets measured at amortized costs. By reducing the number of categories, the IFRS 9 simplifies the accounting treatment of financial instruments. The purpose of the newly established classification criteria based on "business model" is to make accounting information more relevant, comparable, objective and transparent for users. In this paper, we would like to show that the new criteria in IFRS 9 also make room for professional judgment and do not satisfy the goals set up by the professional regulators in terms of transparency and comparability.

Besides introduction and concluding remarks, this paper is divided into three sections. The first one discusses the difference between management intent and business model rules for classification, the second section presents the discussion on the quality of information presented under both models and the third section reports the possible earnings and equity volatility problem caused by both rules of classification.

\section{MANAGEMENT INTENT CLASSIFICATION CRITERIA IN IAS 39 VS. BUSINESS MODEL CRITERIA USED IN IFRS 9}

IAS 39 Financial instruments: recognition and measurement classify all financial instruments into the four categories such as: fair value through profit or loss, loans and receivables, held to maturity and available for sale (see table 1). The classification is based on intent (Leisenring et al., 2011) "for the use, disposition or settlement of financial statement items" (Leisenring et al., 2011). All financial assets are hereby categorized based on management intent regarding the specific financial instrument. Intent is used individually for each asset in question.

Table 1: Classification of financial instruments (assets) in accordance with the IAS 39

\begin{tabular}{cccc}
\hline Category & $\begin{array}{c}\text { Initial } \\
\text { measure- } \\
\text { ment }\end{array}$ & $\begin{array}{c}\text { Subse- } \\
\text { quent } \\
\text { measure- } \\
\text { ment }\end{array}$ & Gains and losses \\
\hline $\begin{array}{c}\text { Fair value } \\
\text { through profit } \\
\text { and loss }\end{array}$ & Fair value & Fair value & $\begin{array}{c}\text { Recognized in } \\
\text { profit and loss } \\
\text { statement }\end{array}$ \\
\hline $\begin{array}{c}\text { Loans and } \\
\text { receivables }\end{array}$ & Fair value & $\begin{array}{c}\text { Amor- } \\
\text { tized cost }\end{array}$ & $\begin{array}{c}\text { Recognized in } \\
\text { profit and loss } \\
\text { statement }\end{array}$ \\
\hline $\begin{array}{c}\text { Held to } \\
\text { maturity }\end{array}$ & Fair value & $\begin{array}{c}\text { Amor- } \\
\text { tized cost }\end{array}$ & $\begin{array}{c}\text { Recognized in } \\
\text { profit and loss } \\
\text { statement }\end{array}$ \\
\hline $\begin{array}{c}\text { Available for } \\
\text { sale }\end{array}$ & Fair value & Fair value & $\begin{array}{c}\text { Fair value move- } \\
\text { ment initially } \\
\text { taken to other } \\
\text { comprehensive in- } \\
\text { come and recycled } \\
\text { to profit and loss }\end{array}$ \\
\hline
\end{tabular}

Source: Grant Thorthon (2009, p. 13)

Fair value through profit and loss category is based on the intent of managers to designate the financial instrument "held principally for sale in the short term" (Grant Thornton, 2009). In the category named loans and receivables entity would place instruments that have "no intention to sell in the short term" (Grant Thornton, 2009). In the held to maturity category, entity would categorize the instruments that entity "has positive intention and ability to hold to the maturity" (Grant Thornton, 2009). In the available for sale category the instruments are classified only if the previous three principles of classification are not met. According to the above mentioned, it seems that the accounting based on intent use the individual criteria set up in management plans regarding the specific instruments. It means that managers approach the instrument on an individual basis (case by case) and then they discuss the category to place the instrument. We cannot forget that in this context the measurement rules affect the recognition of gains and losses regarding the instruments. This basis for classification is not free from judgment and from the possibility that managers may designate the financial instrument into the category that is favorable from the standpoint of recognizing losses and gains and not from the standpoint of real intent and plans to use this instrument.

IFRS 9 introduced in July 2014 establishes the following categories for financial instruments: amortized costs group, fair value through profit and loss and fair value through other comprehensive income (see picture 1). The asset will be classified into one of these categories based on the entity business model and the contractual cash flow characteristics of the instrument itself. In the amortized cost section financial instruments are classified only if they have the characteristics of solely payment of principal and interest (SPPI criteria) and that business model dictates "the hold to collect". Financial asset can be categorized in the group of fair value through other comprehensive income if business model is "collect the contractual cash flow and sell the assets" and if it meets the SSPI criteria. All other assets are classified into the fair value through profit and loss. The last one is the residual category where financial instruments that do not meet the criteria for amortized cost and fair value through other income group are recognized. According to the newly established criteria, it seems that managers classify the instruments using the two interrelated approaches: business model and cash flow. IFRS 9 reduces the number of categories and makes more transparent rules for the classification.

Business model presents "the way the entity manages its financial assets in order to generate the cash flow" (KPMG, 2014). The business model determines whether the financial instrument has a purpose of being used to collect the cash flow or to sell it to other parties or both transactions.

A business model refers to management's use or disposition of assets with the understanding that these actions are undertaken with a profit motive (Leisenring et al., 2011). So, more detailed rules for classification exists in the IFRS 9 in comparison with the IAS 39. According to the above presented, two models (management intent vs. business model) differs in respect of the level at which they operate. Business model operates at the level of entity as a whole while intent model operates a the level of the individual item (Leisenring, et al., 2011). The same authors also pointed out that the business model depends on the economic conditions (hold for use or dispose the assets) and it is more stable because it represents the strategy for the whole company on a portfolio basis. Business model is determined by the "key management personnel" (Leisenring et al., 2011), while the management intent works as a "case to case" principle and the changes in that model are not so obvious when the instrument is reclassified. 


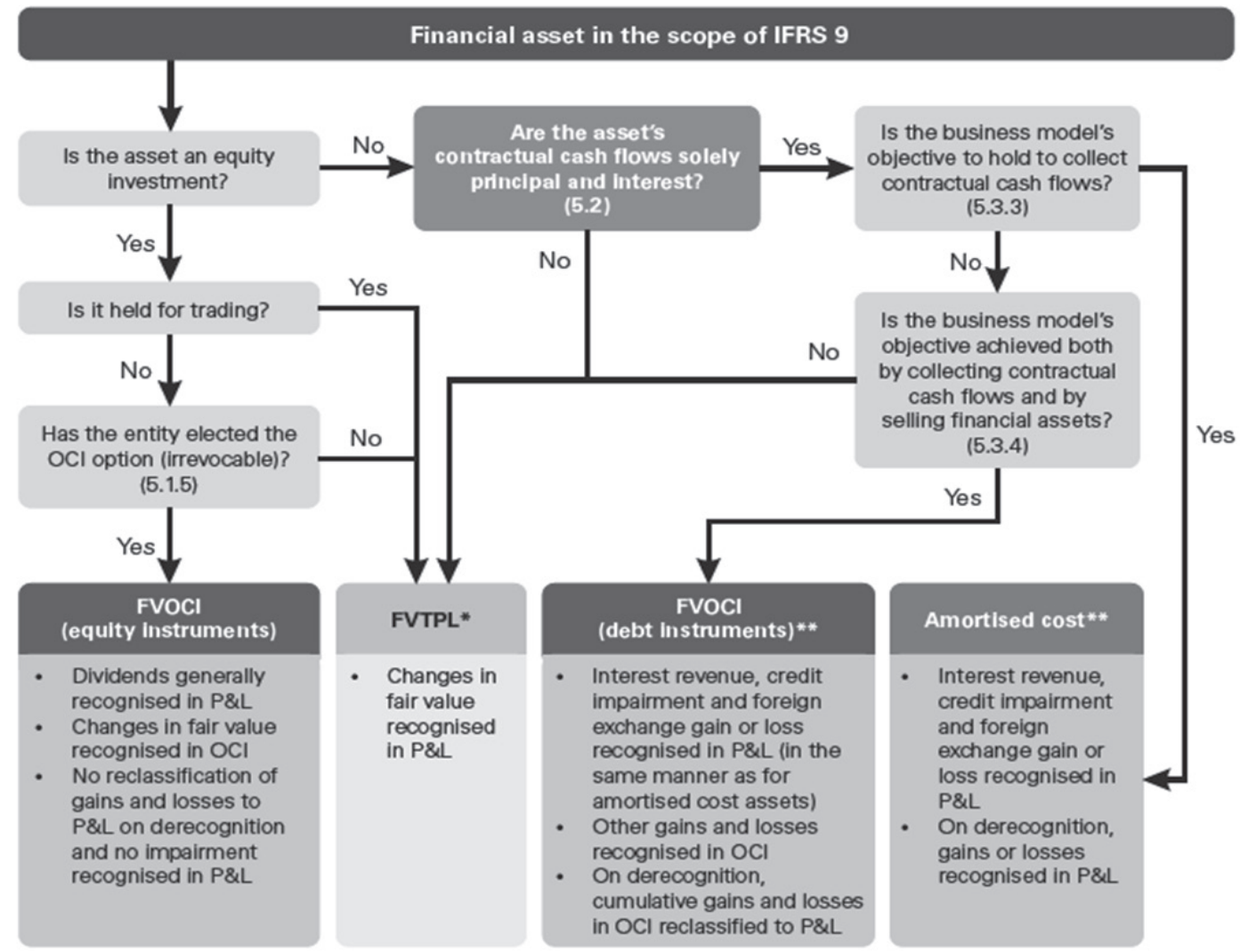

Picture 1. Classification of financial assets into groups within the scope of IFRS 9

Source: KPMG (2014, p. 11)

\section{EFFECTS OF CLASSIFICATION RULES ON THE QUALITY OF THE ACCOUNTING INFORMATION}

The main characteristics of the accounting information are relevance, verifiability and comparability. The criteria established by the IAS 39 which are based on management intent have a purpose of being relevant for the financial statement users. This means that the intent and grouping the financial instruments lead to relevant information. Case by case principle regarding the instruments in IAS 39 means that the entity management has a unique approach towards all instruments and discusses each instrument in terms of intent to hold to maturity, or to sell or both. That is why the information is relevant. Accounting by intent satisfies the relevance criteria because the information is relevant when it is useful when making business decisions by users. The emphasis on relevance is the key goal imposed by the standard setters when introducing the IAS 39. But the intent criteria do not follow the comparability principle. It seems that the same instrument can be differently classified by two different entities if the intents are different. The verifiability is not supported by the intent classification, because we need assurance as to what that intent is, and what kind of documentation or evidence the entity managers need to disclose. In practice, it works with the footnotes that accompany financial statements where managers explain the intent for the classification: This description is in most of the cases based on the principle of copying the standard itself and not explaining the rules used for a specific instrument in question.

The business model criteria for classification are developed in order to promote the relevance, verifiability and comparability between the entities disclosing the financial mation because it presents the objective evidence in order to group the financial assets and that evidence is based on the following (KPMG, 2014):

a) How the performance of the business model are evaluated and reported to the entity key personnel,

b) The risks that affect the performance of the model and the way the risk is managed,

c) How managers of a business model are compensated (using the fair value of the assets or the cash flow).

Relevance is determined when the users have enough information to see the cash flow generated by the asset in question. From the above presented evidence, users, when confronted with the business model, can easily asses the cash flow and future prospects of that instrument. So, in terms of relevance, the business model and IFRS 9 classification rules are more relevant.

The comparability is not supported by the business mod$\mathrm{el}$, because it seems that two similar financial instruments can be categorized differently by two entities. The same is true for the IAS 39. Both standards do not meet the comparability criteria.

With so much evidence of the business model, the verifiability as a goal is attained within the IFRS 9. Business model can be viewed as more relevant and verifiable and as a "matter of fact that can be observed" (IFRS 9, BC27). Schipper (2012), correctly states "that if a business model is a plan for taking actions, and intent is an objective or goal... than the difference of the two is the level at which they operate".

If we take other factors of quality into consideration, such as costs for preparers and auditors, it is obvious that the business model requires more time and effort so it does not pass the cost criteria in comparison with the IAS 39. 


\section{EFFECTS OF IFRS 9 CLASSIFICATION RULES ON VOLATILITY OF EARNINGS AND EQUITY}

Each standard proposed by the standard setters is related to the volatility of earnings. Rule of thumb states that if a standard does not affect the earnings, it will be adopted earlier or companies will postpone the implementation of the standard if it affects their profitability. In order to assess the earnings fluctuations of the IFRS 9 vs. IAS 39, we will take into consideration the fact that the earnings or profit is affected by the group in which each of the instruments is classified. Furthermore, it seems that the classification rules determine the way the profit is affected. The way in which a financial instrument is classified influences the equity position of that company or capital requirements if banks/financial companies are considered. Banks need to comply with the Basel capital requirements or other national requirements. It means that the new standard will have an effect on changes in equity and volatility in profit, which in turn impacts the key performance indicators.

The early adopter of the IFRS 9 may expect the following effect on earnings if instruments are classified into fair value through profit and loss category:

a) Pessimistic scenario - if the financial markets experience a decline in value of the financial instruments measured by a specific company, the profit figure will be affected because the losses on revaluation will affect the income statement and reduce profit,

b) Optimistic scenario - if financial markets experience an increase in value of the financial instruments, the unrealized gains will increase profit, which will have a positive effect on earnings.

If assets are classified into the category named fair value through other comprehensive income, the following may be expected:

a) Pessimistic scenario - if the financial markets experience a decline in value of the financial instruments measured, the earnings will not be affected because the losses will be postponed into the other comprehensive income category and rests within the equity section, but this will affect the amount of equity (reduction in equity),

b) Optimistic scenario - if the financial markets experience an increase in value of the financial instruments, the unrealized gains will increase the equity.

If assets are classified into the amortized cost category, there will be no earnings or equity effects because no revaluation adjustments are applied in this category. In the amortized cost category only historical cost is used for measurement. But if the specific instrument does not meet the credit loss criteria at the end of the period (impairment test) the IFRS 9 requires the earlier recognition of credit losses without waiting the evidence of a loss. This would decrease the earnings in the period of credit loss recognition. IFRS 9 in terms of volatility of earnings and equity makes the profit more volatile so the early adopters may expect investors not to see this as a positive signal. In terms of credit losses recognized earlier and proposed by the IFRS 9, this could be a good signal for investors and increase their confidence in a company. In this respect, investors will be able to assess the risk of a company portfolio of financial instruments, especially loans to whom the credit risk model is addressed.

\section{SUMMARY}

IFRS 9 Financial instruments introduced by the IASB in July 2014 proposed new criteria for the classification of financial instruments based on the business model. The former IAS 39 presents the management intent as a rule to classify the instruments into the categories. The classification rules influence the measurement rules and the profitability of a company. Management intent was criticized as a quite vague rule, where no evidence of intent is disclosed in the footnotes. Business model introduced by the IFRS 9 presents more formal criteria for classification. In this paper we tried to distinguish between business model and management intent based on the comparability, verifiability and relevance of the accounting information presented by both models. We found no evidence that the business model provides more comparable information than the management intent model, because it allows changes in classification and two similar instruments to be classified differently by two entities. We also found that the relevance of the business model and its verifiability is likely to be satisfied. Business model is more costly to be implemented then the previously stated management intent model. For the early adopters of the IFRS 9, the relevant issue is its influence of the earnings and equity. In the last section of the paper the discussion regarding the earnings volatility and equity volatility is mentioned. Two scenarios are presented; optimistic, which increases the equity and profit, and pessimistic that decreases the profit and equity. Both scenarios are likely to be realized but the pessimistic scenario seems more probable.

\section{REFERENCES}

Botosan, C., \& Hufman, A. (2013). Decission useful asset measurement from a business valuation perspective. Preuzeto 27. oktobra 2015. sa http://papers.ssrn.com/sol3/papers.cfm?abstract_ id $=2376854$

European Security and Markets Authority. (2015). EFRAG Draft Endorsement advice on adoption of IFRS 9 Financial instruments. Preuzeto 7. oktobra 2015. sa https://www.esma.europa. eu/system/files/2015-esma-1056_-_esma_response_to_efrag draft_endorsement_advice_on_ifrs_9_0.pdf

Grant Thornton. (2009). Financial Instruments - A Chief Financial Officer's guide to avoiding the traps. Preuzeto 17. oktobra 2015. sa https://www.grantthornton.com/staticfiles/GTCom/ files/GT\%20Thinking/IFRS_Resource_Center/Financial\%20 Instruments\%20(April\%202009).pdf

KPMG. (2014). First Impression: IFRS 9 Financial instruments. Preuzeto 7. oktobra 2015. sa http://www.kpmg.com/TR/tr/ hizmetlerimiz/Audit/Documents/4-first-impressions-ifrs9financial-instruments.pdf

Laux, C., \& Leuz, C. (2009). Did the fair value accounting contribute to the financial crisis. Journal of Economic Perspective, 24(1), 93-118. doi:10.3386/w15515.

Leisenring, J., Linsmeier, T. Schipper, K., \& Trott, E. (2011). Business Model (intent) based accounting. Accounting and Business Research, 42(3), 329-344. doi:10.1080/00014788.2012.681860

Schipper, K. (2012). Business model based (Intent-based) accounting. Preuzeto 7. oktobra 2015. sa http://www.cass.city.ac.uk/_media/internals/easy-edit-suite/wym?a=130263 


\section{MSFI 9 I UTICAJ KRITERIJUMA ZASNOVANIH NA NAMERI MENADŽMENTA I KRITERIJUMA POSLOVNOG MODELA NA KVALITET RAČUNOVODSTVENIH INFORMACIJA}

\section{Apstrakt:}

Svrha ovog rada je da obuhvati promene koje je doneo novi računovodstveni standard MSFI 9 - Finansijski instrumenti vezano za klasifikaciju finansijskih sredstava i posledice koje ta klasifikacija ima na finansijsku poziciju privrednog subjekta i rezultate poslovanja u odnosu na kriterijume klasifikacije prethodnog standarda MRS 39 - Finansijski instrumenti: priznavanje i vrednovanje. Publikovanje standarda MSFI 9 predstavlja poslednji korak IASB projekta o finansijskim instrumentima koji je finaliziran u julu 2014. godine. MSFI 9 je obelodanio da je osnovni kriterijum klasifikacije finansijskih instrumenata u računovodstvu "poslovni model”. Ovaj model zasniva se na ugovorenom novčanom toku (eng. cash flow) koji će taj instrument da odbaci ili na onaj koji će da generiše usled odluke da se instrument proda iz portfolia. Zagovornici standarda MSFI 9 smatraju da su kriterijumi poslovnog modela dobro strukturirani, jasni, objektivni i da se mogu lako primeniti.

Prethodni kriterijumi iz MRS 39 zasnovani su na "nameri menadžmenta" što je dovelo do proizvoljnog tumačenja date namere za razvrstavanje instrumenata i ostavilo prostor za profesionalno rasuđivanje i uticalo na promenljivost dobitka. Svrha ovog rada jeste da ukaže na činjenicu da promena kriterijuma klasifikacije nije zadovoljila date ciljeve. Naime, ciljevi komparabilnosti finansijskih izveštaja i stabilnosti dobitka nisu postignuti. Ostvareni su jedino ciljevi koji se tiču relevantnosti i povreljivosti informacija.
Ključne reči:

MSFI 9,

finansijski instrumenti, kriterijumi razvrstavanja, fer vrednost, namera menadžmenta, poslovni model. 